\title{
Analysis of the Critical Success Factors for Enterprise Resource Planning Implementation from Stakeholders' Perspective: A Systematic Review
}

\author{
Ali Tarhini ${ }^{1}$, Hussain Ammar ${ }^{1}$, Takwa Tarhini ${ }^{2} \&$ Ra'ed Masa'deh ${ }^{3}$ \\ ${ }^{1}$ Department of Information System, Brunel University, London, United Kingdom \\ ${ }^{2}$ Department of Electrical and Computer Engineering, Texas A\&M University, Qatar \\ ${ }^{3}$ Department of Management Information Systems, The University of Jordan, Jordan \\ Correspondence: Ali Tarhini, Department of Information System, Brunel University, London, United Kingdom. \\ E-mail: ali.tarhini@hotmail.co.uk
}

Received: January 30, 2015

Accepted: February 10, 2015

Online Published: March 25, 2015

doi:10.5539/ibr.v8n4p25

URL: http://dx.doi.org/10.5539/ibr.v8n4p25

\begin{abstract}
The successful implementation project of the Enterprise Resource Planning (ERP) has many benefits for the implementing organisation. However, on other side, failing this project would have several negative implications not only on the business but also on the ERP vendor. Therefore, considering all the factors that might affect the success of this project is considered as a priority for all parties involved in this project. Many papers or journal articles have studied the Critical Success Factors (CSFs) that influence the ERP implementation and post implementation phases, however, very few has considered them from the stakeholders' perspective. Hence, this research will fill this gap by providing a systematic review for the literature related to CSFs in the ERP implementation and also present them while considering the participants' different perspectives. This paper presents a systematic review of 35 research articles published on the CSFs implementation between 2000 and 2013. We collected and analysed 35 of the key articles discussing and analysing ERP implementation. The paper identifies a total of $51 \mathrm{CSFs}$ in ERP implementation. In these $51 \mathrm{CSFs}$, top management support and commitment, training and education, project management, clear vision and objectives of the ERP system, careful change management and Interdepartmental communication were the most frequently cited as the CSFs to the successful implementation of ERP systems. A better understanding of the CFSs will help the practitioners and managers to improve the chance of success in the implementation projects.
\end{abstract}

Keywords: Critical Success Factors (CSF), Enterprise Resource Planning (ERP), information technology, literature analysis

\section{Introduction}

The development of information and communication technologies (ICTs) has provided the companies with significant opportunities to reduce the cost of provision and increase their revene (Tarhini et al., 2015a; 2015b; Alenezi et al., 2015). Companies with all sizes, small, mid-size or large have a need to make their Business Processes standardized, therefore, streamline their operations and improve the efficiency of these processes (Tarhini et al., 2015c; Orozco et al., 2015; Abbasi et al., 2015). Enterprise Resource Planning (ERP) system is an information system that helps the organization to coordinate and integrate information within departments. It is one example of the other Enterprise Systems (ES), such as Supply Chain Management (SCM) system, which manages raw materials and products supply. ERP system gives the company the ability to manage its internal business processes (Monk \& Wagner, 2009; Van-Hau \& Kuzic, 2010). Also, it gives the organization an integrated software application with integrated modules for each department in the company with a unified database for all departments, which makes it easier to manage, execute, store data and monitor core business processes: Procurement, Production and Fulfilment processes (Magal \& Word, 2009) as well as other departments' functionalities such as human resources, sales, production and accounting units.

Despite the benefits that accompany the implementation and usage of the ERP system in an organisation, not all ERP implementations are successful (Wong et al., 2005; Grossman \& Walsh, 2004; Yang \& Su, 2009). For example a research conducted by (Xue, Liang, Boulton, \& Snyder, 2004), analysed many failed ERP 
implementations in china, and explained why these failures affected not only the implementing company, but also the ERP vendors, because the vendor had to pay compensation to the implementing firm. One example of these cases when CosmeticCo Company chose MOVEX software as an ERP package, however, this system was not fully translated to Chinese language and the financial tables were not compatible with the requirements of the Chinese government, which causes a lot of delay in the manufacturing process, and as a result, the service provider had to pay USD 250,000 to CosmeticCo Company. Another failure example, is when FurnitureCo Company selected SAP R/3 as an enterprise system, however, this system was not about to adapt to the type of Chinese market where the prices of raw materials are changing frequently and fast, which caused huge discrepancies between the reported and real prices. Eventually, FurnitureCo Company decided to implement local ERP system that met its needs. Moreover, from organizational point of view, implementing ERP solution would impact the organizational structure of the implementing firm, which would need careful change management, involving changing of roles, procedures and policies within the company. Lastly, from the business perspective, the need for Business Process Reengineering (BPR) to fit system functionalities or already embedded business processes, could be considered as the most important effect of implementing ERP solution (Francoise, Bourgault, \& Pellerin, 2009).

Another case study presented by (Barker \& Frolick, 2003), gives an example of a failure ERP implementation, in which the implementing company is considered as the largest independent bottlers in the soft drink industry. It grew through many years and this growth was associated with the use of many information systems, in which there was no integration among them. Therefore, the managers decided to implement an ERP system that provides integration between departments and would benefit the business in many other ways. However, there were some errors that eventually led this project to be failure. First example is that they did not go with the ERP consultants' recommendation for this implementation and chose to do their ideas for this plan. The second issue was the inexperienced understaffed IT department that the organisation had at that time, which made many problems for the deployment process. Moreover, the communications between project members was not managed successfully, there was no proper training for project members and the employees were not selected carefully to suite this mission. Finally, and on the top of all what mentioned before, the management support was not up to the event. All the previous mentioned reasons forced some employees to resign, which added additional problem to the company. From this case study, it can be seen the importance of the previously mentioned success factors and how these would affect such an important project for any organisation. Also, the close communication and collaboration between external consultants and the employees from the company has a great impact on the success of such a project. Presenting the previous case studies has highlighted the significance of studying and investigating the CSFs in ERP implementation.

There are many factors that have to be considered in order to perform successful ERP implementation. Based on that, many authors highlighted the Critical Success Factors (CSF) of any ERP system implementation projects. These factors were results of many implementation cases in different organisations. For example (Haft \& Umble, 2003) mentioned some of these factors such as, clear definition of the strategic goals of the company and whether the system would help to achieve these aims or not, top management support and commitment, and users training. Also, Salimifard et al. (2010) gave other factors, such as the use of the consultants, technological infrastructure and an effective communications between the implementation project members. Moreover, Dezdar and Ainin, (2011) added another two issues that are related to successful Implementation venture, such as user satisfaction and organisational impact.

From the CSFs list mentioned above, it can be seen that there are different user groups that are interested in those factors. First group is the implementation consultants who are responsible about understanding the company's current business processes and aligning them to the processes that are already configured and programmed in the ERP system. The second group comprises the general managers and directors in the implementing company who have to support the project and provide it with the required resources such as budget and dedicated employees. The third group includes Information Technology (IT) managers, Management of Information System (MIS) managers and Chief Information Officer (CIO) in the implementing company who will work closely with the implementing consultants in order to achieve the goals of the project. The fourth group is the vendors who produce these enterprise systems. The last and very important group contains the end users of this giant software.

Depending on the previous explanation, however, the previous mentioned success factors are not classified according to their respective audiences. Also, according to the publications within this field, the job of determining the importance of each factor by counting how many times each element is mentioned within the related literatures is not done yet. Therefore, the need to categorise the previous mentioned factors according to each concerned party involved in this implementation as well as the necessity to measure the authors agreement 
on them have emerged.

Therefore, the aim of this project is to classify the Critical Success Factors (CSFs) in ERP implementation derived from the literatures according to the stakeholders' point of view. This can be done through categorizing the previous mentioned factors according to each party involved as well as measuring the literature consensus on them. This categorisation will be accomplished using a systematic literature review of the related journal papers. This classification would be beneficial for the concerned stakeholders, who are involved in the ERP implementation project, for two reasons. The first one is that it would provide an understanding of the different stakeholder's views about the CSFs. The second reason is that they will be able to focus on the CSFs that are related to them, which would be reflected in a better ERP implementation project.

\section{Background}

\subsection{The Need for Integration and ERP as a Solution}

The need for integration became more important with companies' transformation from the functional style of operation to business process structure, where all departments collaborate together to achieve the required business objective. This change is reflected in the necessity to integrate diverse technologies from different department, to merge business units into a unified software and database, and to improve business performance by having better insight of the company's information (Magal \& Word, 2009), which can be accomplished by using ERP systems as platforms for business integration.

Enterprise Resource Planning (ERP) system assists the organizations to automate their business processes by coordinating and integrating the information between departments, which is one of the big benefits of this system (Monk \& Wagner, 2009). It provides the organization with cross-functional enterprise software with integrated modules for each department in the organisation with a unified database for all of them, which makes it easier for the company to manage, execute, store data and monitor core business processes: Procurement, Production and Fulfilment processes (Magal \& Word, 2009) as well as other departments' functionalities such as marketing, human resources, sales, production and accounting units. The integration it brings and provides is very important for any business, since the ERP system solves the silo effect that legacy systems have, because they were developed in isolation from each other.

The ERP implementation project is considered as a complicated project since it involves many steps and it is related to every aspect in the business which requires a huge team-work and collaboration between all business's functions within the organisation such as IT, finance, manufacturing and Human resources (HR). It is the project that would affect the future of the business on a strategic level. Successfully implementing this system would have a great positive impact on the company. In contrast, failing this project would have a major negative impact on the implementing company. Therefore, many considerations and success factors have to be well thought off and many mistakes and risks have to be avoided in order to see this project a successful one.

\subsection{The Implications of the ERP Implementation}

Having the Enterprise Resource Planning (ERP) system implemented successfully would have an important impacts and benefits on the organisation. These implications can be evaluated according to different viewpoints. One perspective is about gains and losses, and this can be evaluated by analysing case studies where companies implemented ERP systems. One example of these is the study conducted by (Yang \& Su, 2011), which shows the benefits of having ERP system on the organisation and effect of this enterprise system on other areas or IT systems such as the Supply Chain Management (SCM) system that is integrated with it. These benefits are presented in Figure 1. 


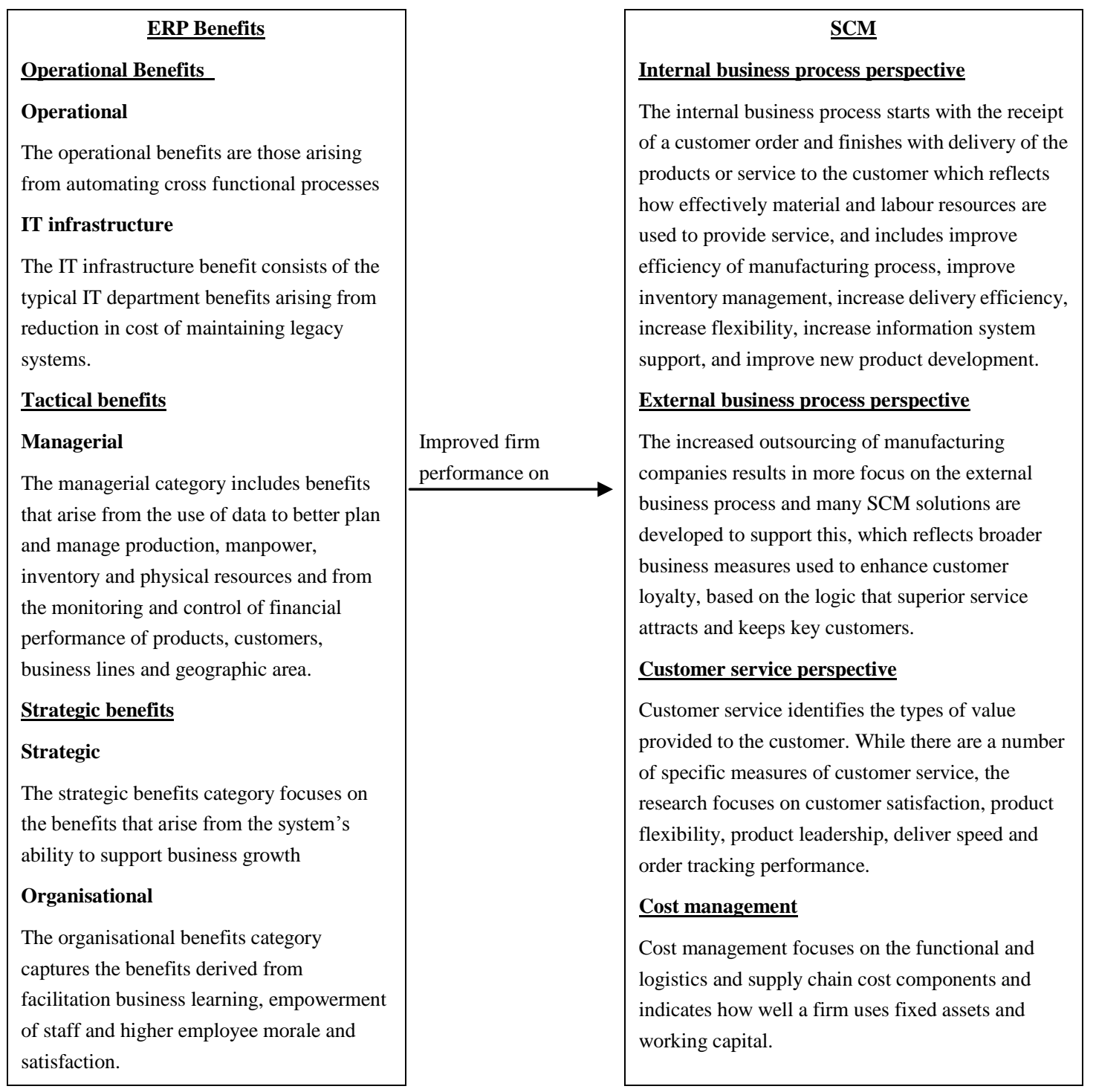

Figure 1. Linking ERP benefits and firm performance of SCM

\section{Methodology}

The process for this research is based on the five steps proposed by (Khan et al., 2003) for the research based on systematic review, in which the authors provided an explanation of the tasks accompanying a systematic literature review such as selecting, reviewing and quality assessment of the reviewed literatures. The five steps are and the actions taken by the researchers are follows:

\section{1- Framing the question for the review.}

In this step, the research question and the related terms should be clearly specified before the start the of the actual literature review. In the case of this research, there are two parts or two research questions:

1) To identify the Critical Success Factors CSFs in ERP implementation and post implementation phases;

2) To classify the identified CSFs according to the stakeholders' point of views.

\section{2- Identifying relevant work and literatures.}

In this step of this research, the resources of the relevant literatures should be identified. For this study, the focus is on the electronic resources and documents that contain the following keywords: 'enterprise resource planning', 'ERP Implementation' and 'critical success factors CSFs'. More specifically, the resources were journals that are concerned with ERP research in IT, computing and business management such as (European Journal of Operational Research, Science Direct, IEEE Xplore, Journal of Enterprise Information Management, Association 
for Information Systems).

3-Assessing the quality of the found studies.

In this step, the discovered papers or publications would be filtered according to some quality measures to filter the found publications. These standards are:

- The paper must clearly relate to the research question

- The publication must have clear methodology

- The research must come from trusted resources and journals. In this regard, papers that are based on a single case study were excluded, since the findings cannot be generalised

- The publication year of the papers must be 2000 or above

4- Summarising the discovered evidences that answer the research question.

In this step, the discovered evidences related to the research questions will be gathered and summarised in order to prepare them for fifth step which is data analysis or findings interpretations.

\section{5- Understanding the findings.}

In this final step of the study, the discovered results from the previous steps would be analysed in order to conclude the stakeholders groups in the ERP implementation project as well as CSFs that concern each of these groups.

Critical Success Factors can be defined as the aspects or elements that need to be considered carefully in order to have a successful project. This definition can be applied to the ERP implementation projects. Based on this explanation and on the importance of examining the Critical Success Factors in ERP Implementation, 34 articles have been investigated thoroughly in order to determine their relevance to the topic under investigation and also to answer the research questions for this study. Table 1 lists the 20 articles that have been examined and accepted and Table 2 lists the 14 papers that were examined and rejected. These articles were rejected because one or more of the following reasons:

- The year of publication is older than 2000

- Some articles were based on single case studies

- Some papers were not related directly to the CSFs in ERP implementation

- Some articles were about specific and not important industry sector.

- Some papers were based on previously published conference proceedings and then updated and published in an international journal.

The keywords that were used to filter the papers in this part of the study are: (ERP Implementation) and (Critical Success Factors) or (CSFs)

Table 1. The accepted CSFs related articles

\begin{tabular}{|c|c|c|c|}
\hline \# & Title & Authorls & Year \\
\hline 1. & $\begin{array}{l}\text { Examining critical success factors affecting ERP implementations in } \\
\text { enterprises of Pakistan }\end{array}$ & $\begin{array}{l}\text { Khattak, M.O., Yuanguan, S., Irfan, M., Khattak, } \\
\text { R. A., Khattak, M. S. M. }\end{array}$ & 2012 \\
\hline 2. & $\begin{array}{l}\text { The Critical Success Factors Across ERP Implementation Models: An } \\
\text { Empirical Study in China }\end{array}$ & Lai, I. K. W. & 2006 \\
\hline 3. & Critical success factors for ERP implementation in SMEs & Munir, A. M., Pinedo-Cuenca, R. & 2013 \\
\hline 4. & $\begin{array}{l}\text { The consistency among facilitating factors and ERP implementation } \\
\text { success: A holistic view of fit }\end{array}$ & Wang, E. T. G., Shih, S. P., Jiang, J. J., Klein, G. & 2008 \\
\hline 5. & $\begin{array}{l}\text { A Classification Framework of Critical Success Factors for ERP } \\
\text { Systems Implementation: A Multi-Stakeholder Perspective }\end{array}$ & Nour, M. A., Mouakket, S. & 2011 \\
\hline 6. & Critical success factors for ERP implementations in Belgian SMEs & Doom, C., Milis, K., Poelmans, S., Bloemen, E. & 2009 \\
\hline 7. & Enterprise resource planning: A taxonomy of critical factors & Al-Mashari, M., Al-Mudimigh, A., Zairi, M. & 2003 \\
\hline 8. & $\begin{array}{l}\text { ERP Implementation: A multi-stakeholder analysis of critical success } \\
\text { factors }\end{array}$ & Chetcuti, H. R. & 2008 \\
\hline
\end{tabular}


9. $\quad$ Enterprise resource planning: Implementation procedures and critical $\quad$ Umble, E. J., Haft, R. R., Umble, M. M. 2003 success factors

10. Vicious and virtuous cycles in ERP implementation: a case study of Akkermans, H., Helden, K. interrelations between critical success factors

11. Critical Success Factors In ERP Implementation: A Review

Al-Fawaz, K., Al-Salti, Z.,

12. Critical Success Factors in International ERP Implementations: A

Eldabi, T.

Case Research Approach

Pant, R., Willcocks, L.

13. The influence of organizational factors on successful ERP

Dezdar, S., Ainin, S. implementation

14. CSF of ERP in Australia

Dagher, J., Kuzic, J.

15. Evaluation of Key Success Factors Influencing ERP Implementation Success

Hailu, A., Rahman, S.

16. Examining the critical success factors in the adoption of enterprise

Ngai, E. W. T., Law, C. C. H., Wat, F. K. T. resource planning

17. ERP implementation through critical success factors' management

Francoise, O., Bourgault, M., Pellerin, R.

18. Success and failure factors of adopting SAP in ERP system

Gargeya, V. B., Brady, C.

19. Investigating Critical Success Factors in ERP Implementation Projects

20. The Impact of Critical Success Factors across the Stages of Enterprise Resource Planning Implementations

Table 2. The rejected CSFs related articles

\begin{tabular}{|c|c|c|c|}
\hline \# & Title & Authorls & Year \\
\hline 1. & Process mapping in successful ERP implementations & Okrent, M. D.,Vokurka, R. J. & 2004 \\
\hline 2. & A classification for better use of ERP systems & Botta-Genoulaz, V., Millet, P. A. & 2005 \\
\hline 3. & A Critical Success Factors Model For ERP Implementation & Holland, C. P., Light, B. & 1999 \\
\hline 4. & $\begin{array}{l}\text { Critical Success Factors for ERP implementation in Chinese Construction } \\
\text { Companies }\end{array}$ & Chan, C. T. W., Sin, H. C. & 2010 \\
\hline 5. & $\begin{array}{l}\text { Enterprise information systems project implementation: A case study of } \\
\text { ERP in Rolls-Royce }\end{array}$ & $\begin{array}{l}\text { Yusuf, Y., Gunasekaran, A., Abthorpe, M. } \\
\text { S. }\end{array}$ & 2004 \\
\hline 6. & $\begin{array}{l}\text { ERP Implementation Critical Success Factors - The Role And Impact of } \\
\text { Business Process Management }\end{array}$ & Jarrar, Y. F., Al-Mudimigh, A., Zairi, M. & 2000 \\
\hline 7. & ERP Implementation Process Analysis Based on the Key Success Factors & Yanhong, Z. & 2009 \\
\hline 8. & $\begin{array}{l}\text { Evaluation of the ERP Implementation at Esfahan Steel Company Based on } \\
\text { Five Critical Success Factors: A Case Study }\end{array}$ & Moohebat, M. R., Jazi, M. D., Asemi, A. & 2010 \\
\hline 9. & $\begin{array}{l}\text { Identifying critical issues in enterprise resource planning (ERP) } \\
\text { implementation }\end{array}$ & Ehie, I. C., Madsen, M. & 2005 \\
\hline 10. & $\begin{array}{l}\text { Identifying Critical Success Factors of ERP Systems at the Higher } \\
\text { Education Sector }\end{array}$ & Rabaa'i, A. A. & 2009 \\
\hline 11. & ERP Implementation in Australia & Dagher, J., Kuzic, J. & 2011 \\
\hline 12. & $\begin{array}{l}\text { Strategic alignment of ERP implementation stages: An empirical } \\
\text { investigation }\end{array}$ & Velcu, O. & 2010 \\
\hline 13. & $\begin{array}{l}\text { The Critical Success Factors for ERP implementation: an organisational fit } \\
\text { prospective }\end{array}$ & Hong, K.K. \& Kim, Y.G & 2002 \\
\hline 14. & $\begin{array}{l}\text { Critical factors for successful ERP implementation: Exploratory findings } \\
\text { from four case studies }\end{array}$ & $\begin{array}{l}\text { Motwani, J., Subramanian, R., } \\
\text { Gopalakrishna, P. }\end{array}$ & 2005 \\
\hline
\end{tabular}




\section{Data Analysis}

The data analysis phase in the systematic literature review will be composed of the following steps:

1) The next step after finding and summarising the related publications is to conclude the stakeholders groups that are involved in the ERP implementation and utilisation.

2) Classifying the discovered CSF into the concluded categories from the previous step.

3) Measuring the agreement among the included publications on the previous summarised CSF.

\subsection{Critical Success Factors CSFs Analysis}

The 20 articles that have been accepted as sources for the CSFs in ERP implementation were analysed thoroughly in order to determine the factors studied by the authors of those papers, in which, 51 different CSFs were identified. They cover organisational, neutral and operational aspects in the business (Munir \& Pinedo-Cuenca, 2013) as well as pre, during and post implementation phases of the ERP system. The importance of considering the discovered factors comes from their significance to have a successful implementation of the ERP package. The discovered factors are listed in Table 3, in which they are presented without a specific order, however, with considering not have the same CSF repeated while examining the journal articles.

Table 3. CSFs identified in the accepted literatures

\begin{tabular}{|c|c|}
\hline CSF \# & CSF Description \\
\hline 1. & Top management support and commitment \\
\hline 2. & Training for different users groups \\
\hline 3. & Clear vision, goals and objectives of the ERP system \\
\hline 4. & Careful change management \\
\hline 5. & The use of ERP implementation consultant \\
\hline 6. & End user involvement \\
\hline 7. & Suitable IT legacy systems \\
\hline 8. & Organizational fit for ERP \\
\hline 9. & Business process re-engineering (BPR) and process management \\
\hline 10. & Project champion \\
\hline 11. & On-going ERP vendor support \\
\hline 12. & Communication among the implementation team members \\
\hline 13. & IT infrastructure \\
\hline 14. & Team Work \\
\hline 15. & IT department capability \\
\hline 16. & Technical issues \\
\hline 17. & Motivational factors to implement ERP systems \\
\hline 18. & Implementation strategies \\
\hline 19. & Minimal customization of packages \\
\hline 20. & Good project scope management \\
\hline 21. & Project management \\
\hline 22. & Experienced project manager-leadership \\
\hline 23. & Adequate resources \\
\hline 24. & Interdepartmental communication \\
\hline 25. & Interdepartmental cooperation \\
\hline 26. & Education on new business processes \\
\hline 27. & Adequate ERP software selection \\
\hline
\end{tabular}




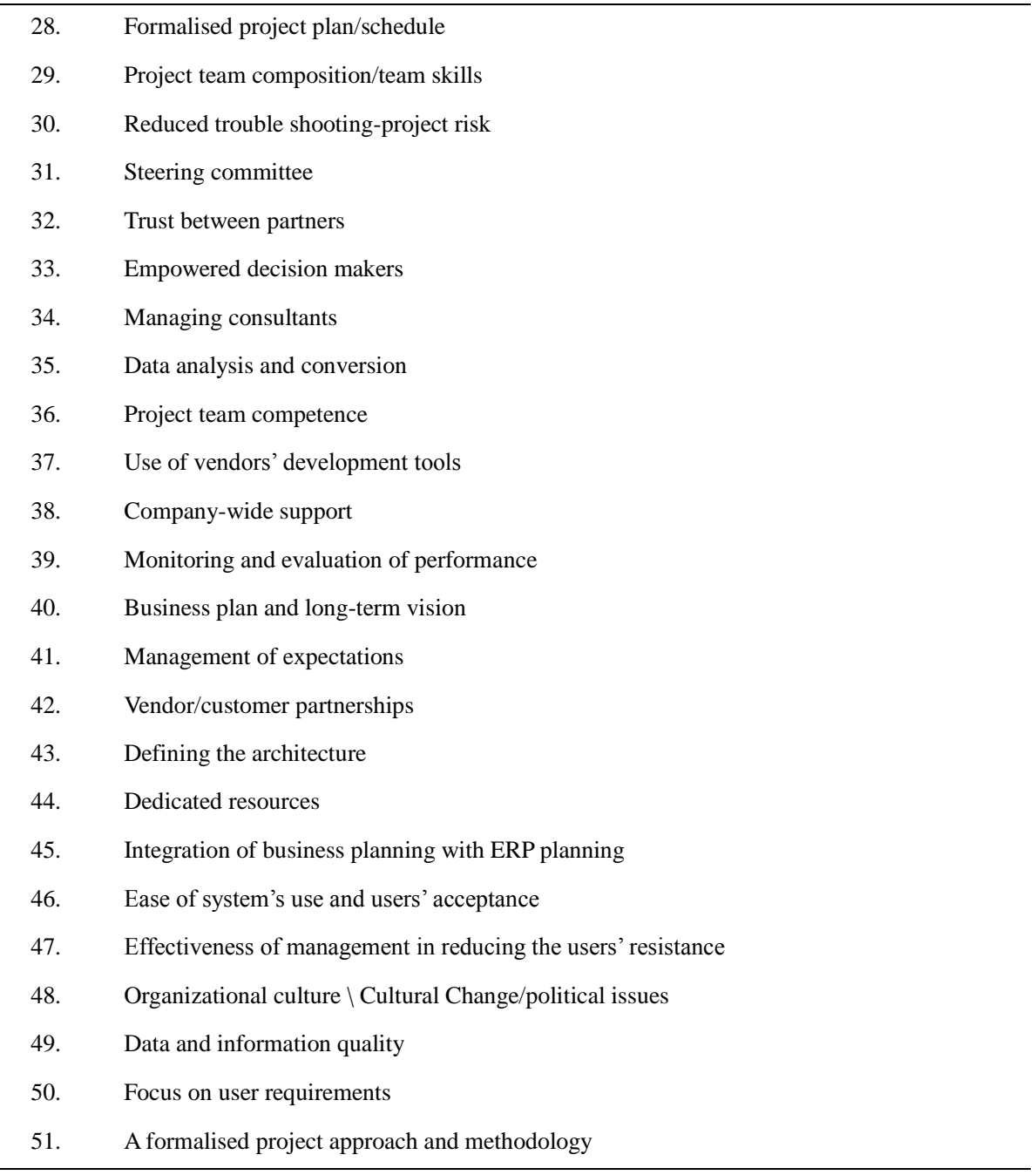

\subsection{Stakeholders in the ERP Implementation Project}

The stakeholders involved in the ERP implementation project can be divided into several groups. This categorisation is important since it provides a way for each group to focus on the CSFs that are relevant to it. Table 4 shows these groups. This categorisation is mainly based on the research done by (Nour \& Mouakket, 2011) and from the CSFs papers.

Table 4. Stakeholders groups in ERP implementation project

\begin{tabular}{cl}
\hline Group \# & Stakeholder Group Name \\
\hline 1. & End user \\
2. & Top management \\
3. & IT Department \\
4. & Project Team \\
5. & Organisation \\
6. & Vendor \\
7. & ERP Consultant \\
8. & Employees from different department \\
9. & Business processes experts \\
\hline
\end{tabular}




\subsection{Measurement of the CSFs Frequency}

This part will analyse and measure the agreement among authors on the CSFs in the ERP implementation that were discovers and listed previously. This measurement will help in deciding the most important success factors. First examination will concentrate on the CSFs frequency in the approved journal articles. Table 5 records the occurrences of the first 25 CSFs from Table 4, and Table 6 does the same for the other 26 CSFs from the same table. The numbers in the first column in Tables 5 and 6 represent the approved articles in table 1 and the numbers at the first row symbolize the CSFs. The difficulty that faced the researcher during the CSFs' frequency investigation was the use of different expressions by the authors for the same CSF.

Table 5. CSFs frequency in the literatures (CSFs 1-25)

\begin{tabular}{|c|c|c|c|c|c|c|c|c|c|c|c|c|c|c|c|c|c|c|c|c|c|c|c|c|c|}
\hline CSFs & 1 & 2 & 3 & 4 & 5 & 6 & 7 & 8 & 9 & 10 & 11 & 12 & 13 & 14 & 15 & 16 & 17 & 18 & 19 & 20 & 21 & 22 & 23 & 24 & 25 \\
\hline 1 & $\checkmark$ & $\checkmark$ & $\checkmark$ & $\checkmark$ & $\checkmark$ & & & & & $\checkmark$ & & $\checkmark$ & $\checkmark$ & & $\checkmark$ & & & $\checkmark$ & & & $\checkmark$ & $\checkmark$ & & & \\
\hline 2 & $\checkmark$ & $\checkmark$ & $\checkmark$ & $\checkmark$ & $\checkmark$ & $\checkmark$ & & & $\checkmark$ & $\checkmark$ & $\checkmark$ & & & & & & & $\checkmark$ & $\checkmark$ & & $\checkmark$ & & & $\checkmark$ & $\checkmark$ \\
\hline 3 & $\checkmark$ & $\checkmark$ & $\checkmark$ & & $\checkmark$ & & $\checkmark$ & & $\checkmark$ & $\checkmark$ & $\checkmark$ & & & & & & & $\checkmark$ & $\checkmark$ & $\checkmark$ & $\checkmark$ & $\checkmark$ & $\checkmark$ & $\checkmark$ & $\checkmark$ \\
\hline 4 & $\checkmark$ & $\checkmark$ & $\checkmark$ & & & $\checkmark$ & & $\checkmark$ & $\checkmark$ & & & $\checkmark$ & & & & $\checkmark$ & $\checkmark$ & $\checkmark$ & & & $\checkmark$ & & & & \\
\hline 5 & $\checkmark$ & $\checkmark$ & $\checkmark$ & $\checkmark$ & & $\checkmark$ & & & & $\checkmark$ & $\checkmark$ & & $\checkmark$ & & & & & & & $\checkmark$ & $\checkmark$ & & $\checkmark$ & & \\
\hline 6 & $\checkmark$ & $\checkmark$ & $\checkmark$ & $\checkmark$ & $\checkmark$ & $\checkmark$ & $\checkmark$ & & & & $\checkmark$ & & $\checkmark$ & & $\checkmark$ & & & & & & & & & $\checkmark$ & \\
\hline 7 & $\checkmark$ & $\checkmark$ & & & & & $\checkmark$ & & & $\checkmark$ & & $\checkmark$ & & & & & & & & & $\checkmark$ & & & $\checkmark$ & \\
\hline 8 & $\checkmark$ & & & $\checkmark$ & $\checkmark$ & & $\checkmark$ & & $\checkmark$ & $\checkmark$ & $\checkmark$ & $\checkmark$ & & & & & & $\checkmark$ & & & & & & & \\
\hline 9 & $\checkmark$ & $\checkmark$ & $\checkmark$ & $\checkmark$ & & & & & & & & & & $\checkmark$ & & & & & & & $\checkmark$ & & & $\checkmark$ & \\
\hline 10 & $\checkmark$ & $\checkmark$ & $\checkmark$ & $\checkmark$ & $\checkmark$ & & & & $\checkmark$ & $\checkmark$ & $\checkmark$ & & & & & & & & $\checkmark$ & & $\checkmark$ & & & $\checkmark$ & $\checkmark$ \\
\hline 11 & $\checkmark$ & $\checkmark$ & $\checkmark$ & & & $\checkmark$ & & & $\checkmark$ & $\checkmark$ & & & & $\checkmark$ & & & & & & & $\checkmark$ & & & & \\
\hline 12 & $\checkmark$ & $\checkmark$ & $\checkmark$ & $\checkmark$ & $\checkmark$ & & & & $\checkmark$ & $\checkmark$ & $\checkmark$ & & & & & & & & $\checkmark$ & & $\checkmark$ & & & $\checkmark$ & $\checkmark$ \\
\hline 13 & $\checkmark$ & $\checkmark$ & & & & & & & & & & $\checkmark$ & & & & & & & & & & & & $\checkmark$ & \\
\hline 14 & $\checkmark$ & $\checkmark$ & $\checkmark$ & & $\checkmark$ & & & & & $\checkmark$ & & & & & & & & & $\checkmark$ & & & & & & \\
\hline 15 & $\checkmark$ & $\checkmark$ & $\checkmark$ & $\checkmark$ & $\checkmark$ & $\checkmark$ & & & & & & $\checkmark$ & & $\checkmark$ & & & & & & & $\checkmark$ & & & $\checkmark$ & \\
\hline 16 & $\checkmark$ & $\checkmark$ & $\checkmark$ & $\checkmark$ & & $\checkmark$ & $\checkmark$ & $\checkmark$ & $\checkmark$ & & $\checkmark$ & $\checkmark$ & & $\checkmark$ & & & & $\checkmark$ & & & $\checkmark$ & & & $\checkmark$ & $\checkmark$ \\
\hline 17 & $\checkmark$ & & & $\checkmark$ & $\checkmark$ & & & & $\checkmark$ & $\checkmark$ & & $\checkmark$ & & $\checkmark$ & & & & & $\checkmark$ & & $\checkmark$ & & & $\checkmark$ & \\
\hline 18 & $\checkmark$ & & & $\checkmark$ & & & $\checkmark$ & & $\checkmark$ & $\checkmark$ & & $\checkmark$ & & $\checkmark$ & & & & & $\checkmark$ & & $\checkmark$ & & & $\checkmark$ & \\
\hline 19 & $\checkmark$ & $\checkmark$ & $\checkmark$ & $\checkmark$ & $\checkmark$ & & & & $\checkmark$ & & & $\checkmark$ & $\checkmark$ & & & & & & & & $\checkmark$ & & & $\checkmark$ & \\
\hline 20 & $\checkmark$ & $\checkmark$ & $\checkmark$ & $\checkmark$ & $\checkmark$ & & & & $\checkmark$ & $\checkmark$ & $\checkmark$ & & & & & & & & $\checkmark$ & & $\checkmark$ & & & $\checkmark$ & $\checkmark$ \\
\hline Frq & 20 & 17 & 15 & 14 & 12 & 7 & 6 & 2 & 12 & 13 & 9 & 10 & 4 & 6 & 2 & 1 & 1 & 6 & 8 & 2 & 16 & 2 & 2 & 14 & 6 \\
\hline
\end{tabular}

Table 6. CSFs frequency in the literatures (CSFs 26-51)

\begin{tabular}{|c|c|c|c|c|c|c|c|c|c|c|c|c|c|c|c|c|c|c|c|c|c|c|c|c|c|c|}
\hline $\mathrm{CSF}$ & 26 & 27 & 28 & 29 & 30 & 31 & 32 & 33 & 34 & 35 & 36 & 37 & 38 & 39 & 40 & 41 & 42 & 43 & 44 & 45 & 46 & 47 & 48 & 49 & 50 & 51 \\
\hline 1 & & & & $\checkmark$ & & $\checkmark$ & & & & & $\checkmark$ & & $\checkmark$ & & & & & & & $\checkmark$ & $\checkmark$ & $\checkmark$ & & & & \\
\hline 2 & $\checkmark$ & $\checkmark$ & & & $\checkmark$ & $\checkmark$ & & & & $\checkmark$ & $\checkmark$ & $\checkmark$ & $\checkmark$ & $\checkmark$ & & $\checkmark$ & $\checkmark$ & & $\checkmark$ & & & & $\checkmark$ & & & \\
\hline 3 & $\checkmark$ & $\checkmark$ & $\checkmark$ & $\checkmark$ & $\checkmark$ & $\checkmark$ & $\checkmark$ & $\checkmark$ & $\checkmark$ & $\checkmark$ & & $\checkmark$ & & $\checkmark$ & & $\checkmark$ & & & & & & & $\checkmark$ & & & \\
\hline 4 & & & & & & & & $\checkmark$ & & & & & & & & & & & & & & & & & & \\
\hline 5 & & & & $\checkmark$ & $\checkmark$ & & & & & & & & & & & & & & $\checkmark$ & & $\checkmark$ & & & $\checkmark$ & & \\
\hline 6 & & & $\checkmark$ & $\checkmark$ & & & & & & & $\checkmark$ & & & & & & $\checkmark$ & & & & & & & $\checkmark$ & $\checkmark$ & $\checkmark$ \\
\hline 7 & & $\checkmark$ & & & & & & & & & & & & & & & & & & & & & $\checkmark$ & & & \\
\hline 8 & $\checkmark$ & $\checkmark$ & $\checkmark$ & $\checkmark$ & $\checkmark$ & & & $\checkmark$ & & & $\checkmark$ & & & & & $\checkmark$ & & & & & & & & $\checkmark$ & & \\
\hline 9 & & & & & & & & & & & $\checkmark$ & & & & & & & & & & & & & $\checkmark$ & & \\
\hline 10 & $\checkmark$ & $\checkmark$ & & & & $\checkmark$ & & & & $\checkmark$ & $\checkmark$ & $\checkmark$ & & & & $\checkmark$ & $\checkmark$ & $\checkmark$ & $\checkmark$ & & & & & & & \\
\hline
\end{tabular}




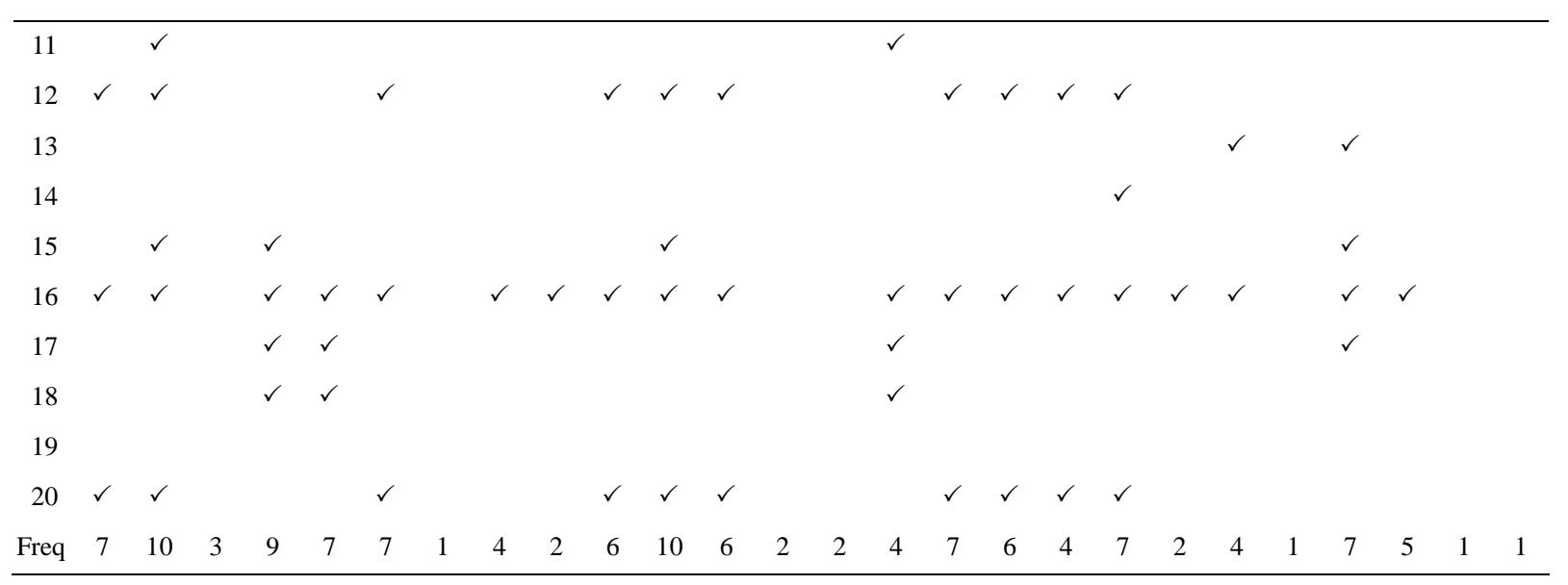

\section{Findings}

Having analysed and presented the results in the previous section. This section will present the main findings from the data analysis section, which is based on the approved articles related to CSFs in the ERP implementation project. It will show the most important success factors as well as the categorisation of these influencers according to the stakeholders groups.

\subsection{Appearance Order of Critical Success Factors CSFs}

Based on the work done in the data analysis chapter, Table 7 lists the CSFs according to their appearance in the literatures that is based on analysis presented in Tables 5 and 6 . This order gives an indication about the most important CSFs in the ERP implementation projects. Based on that, participants concerned with this project can prioritise their attention for the important factors in order to achieve best results, to get the required functionalities, and to meet the expectations from the ERP system.

Table 7. CSFs ordered according to their appearance frequency in the literatures

\begin{tabular}{|c|c|c|}
\hline CSF Order & CSF Description & Frequency \\
\hline 1. & Top management support and commitment & 20 \\
\hline 2. & Training for different users groups & 17 \\
\hline 3. & Project management & 16 \\
\hline 4. & Clear vision, goals and objectives of the ERP system & 15 \\
\hline 5. & Careful change management & 14 \\
\hline 6. & Interdepartmental communication & 14 \\
\hline 7. & Project champion & 13 \\
\hline 8. & The use of ERP implementation consultant & 12 \\
\hline 9. & Business process re-engineering (BPR) & 12 \\
\hline 10. & Communication among the implementation team members & 10 \\
\hline 11. & Adequate ERP software selection & 10 \\
\hline 12. & Project team competence & 10 \\
\hline 13. & On-going ERP vendor support & 9 \\
\hline 14. & Project team composition/team skills & 9 \\
\hline 15. & Minimal customization of packages & 8 \\
\hline 16. & End user involvement & 7 \\
\hline 17. & Education on new business processes & 7 \\
\hline 18. & Reduced trouble shooting-project risk & 7 \\
\hline 19. & Steering committee & 7 \\
\hline
\end{tabular}




\begin{tabular}{|c|c|c|}
\hline 20. & Management of expectations & 7 \\
\hline 21. & Dedicated resources & 7 \\
\hline 22. & Organizational culture $\backslash$ Cultural Change/political issues & 7 \\
\hline 23. & Suitable IT legacy systems & 6 \\
\hline 24. & Team Work & 6 \\
\hline 25. & Implementation strategies & 6 \\
\hline 26. & Interdepartmental cooperation & 6 \\
\hline 27. & Data analysis and conversion & 6 \\
\hline 28. & Use of vendors' development tools & 6 \\
\hline 29. & Vendor/Customer partnership & 6 \\
\hline 30. & Data and information quality & 5 \\
\hline 31. & IT infrastructure & 4 \\
\hline 32. & Empowered decision makers & 4 \\
\hline 33. & Business plan and long-term vision & 4 \\
\hline 34. & Defining the architecture & 4 \\
\hline 35. & Ease of system's use and users' acceptance & 4 \\
\hline 36. & Formalised project plan/schedule & 3 \\
\hline 37. & Organizational fit for ERP & 2 \\
\hline 38. & IT department capability & 2 \\
\hline 39. & Good project scope management & 2 \\
\hline 40. & Experienced project manager-leadership & 2 \\
\hline 41. & Adequate resources & 2 \\
\hline 42. & Managing consultants & 2 \\
\hline 43. & Company-wide support & 2 \\
\hline 44. & Monitoring and evaluation of performance & 2 \\
\hline 45. & Integration of business planning with ERP planning & 2 \\
\hline 46. & Technical issues & 1 \\
\hline 47. & Motivational factors to implement ERP systems & 1 \\
\hline 48. & Trust between partners & 1 \\
\hline 49. & Effectiveness of management in reducing the users' resistance & 1 \\
\hline 50. & Focus on user requirements & 1 \\
\hline 51. & A formalised project approach and methodology & 1 \\
\hline
\end{tabular}

\subsection{CSFs Classification according to Stakeholders Groups}

This section will cover one important objective of this study, which is classifying the discovered CSFs in the literatures according to the stakeholders group identified during previous phase. This categorisation is very important for the people involved in the ERP implementation since they will be able to focus on the factors that concern them, which can possibly reflected in a better performance, and as a result to achieve a successful ERP implementation. Table 8 presents the previous mentioned classification in a tabular format, in which, the order of the CSFs is following the same order as in Table 7. In this table the participants from each category can pay more attention to the highlighted and checked factors in the column that they belong to. 
Table 8. CSFs classification according to stakeholders group

\begin{tabular}{|c|c|c|c|c|c|c|c|c|c|}
\hline $\mathrm{CSF} \backslash$ Stakeholders Group & $\begin{array}{l}\text { End } \\
\text { User }\end{array}$ & $\begin{array}{c}\text { Top } \\
\text { Management }\end{array}$ & $\begin{array}{c}\text { IT } \\
\text { Department }\end{array}$ & $\begin{array}{l}\text { Project } \\
\text { Team }\end{array}$ & Organisation & Vendor & $\begin{array}{c}\text { ERP } \\
\text { Consultant }\end{array}$ & $\begin{array}{c}\text { Employees } \\
\text { from Different } \\
\text { Departments }\end{array}$ & $\begin{array}{c}\text { Business } \\
\text { Processes } \\
\text { Experts }\end{array}$ \\
\hline $\begin{array}{l}\text { Top management support \& } \\
\text { commitment }\end{array}$ & & $\checkmark$ & & & & & & & \\
\hline Training different usersgroups & $\checkmark$ & $\checkmark$ & $\checkmark$ & $\checkmark$ & $\checkmark$ & & & $\checkmark$ & $\checkmark$ \\
\hline Project management & & $\checkmark$ & & $\checkmark$ & & & & & \\
\hline $\begin{array}{l}\text { Clear vision, goals and } \\
\text { objectives }\end{array}$ & & $\checkmark$ & & & $\checkmark$ & & & & $\checkmark$ \\
\hline Careful change management & & $\checkmark$ & & & & & & & \\
\hline $\begin{array}{l}\text { Interdepartmental } \\
\text { communication }\end{array}$ & $\checkmark$ & & & $\checkmark$ & & & & $\checkmark$ & \\
\hline Project champion & & $\checkmark$ & & $\checkmark$ & & & & & \\
\hline The use of ERP consultant & & $\checkmark$ & & & $\checkmark$ & & $\checkmark$ & & $\checkmark$ \\
\hline Business process re-engineering & $\checkmark$ & $\checkmark$ & & & $\checkmark$ & & $\checkmark$ & $\checkmark$ & $\checkmark$ \\
\hline $\begin{array}{l}\text { Communication among team } \\
\text { members }\end{array}$ & $\checkmark$ & & $\checkmark$ & $\checkmark$ & & & $\checkmark$ & $\checkmark$ & $\checkmark$ \\
\hline $\begin{array}{l}\text { Adequate ERP software } \\
\text { selection }\end{array}$ & & $\checkmark$ & $\checkmark$ & & & & & & $\checkmark$ \\
\hline Project team competence & & $\checkmark$ & & $\checkmark$ & & & & & \\
\hline On-going ERP vendor support & & & & & & $\checkmark$ & & & \\
\hline Project team composition & & & & $\checkmark$ & & & & & \\
\hline $\begin{array}{l}\text { Minimal customization of } \\
\text { packages }\end{array}$ & & & & & & & $\checkmark$ & & $\checkmark$ \\
\hline End user involvement & $\checkmark$ & & & & & & & $\checkmark$ & \\
\hline $\begin{array}{l}\text { Education on new business } \\
\text { processes }\end{array}$ & $\checkmark$ & $\checkmark$ & & & $\checkmark$ & & $\checkmark$ & $\checkmark$ & $\checkmark$ \\
\hline $\begin{array}{l}\text { Reduced trouble } \\
\text { shooting-project risk }\end{array}$ & & & $\checkmark$ & & & & & & \\
\hline Steering committee & & $\checkmark$ & $\checkmark$ & $\checkmark$ & $\checkmark$ & & & $\checkmark$ & $\checkmark$ \\
\hline Management of expectations & & $\checkmark$ & & $\checkmark$ & & & $\checkmark$ & & $\checkmark$ \\
\hline Dedicated resources & & $\checkmark$ & $\checkmark$ & & $\checkmark$ & & & & \\
\hline Organizational cultural Change & & $\checkmark$ & $\checkmark$ & $\checkmark$ & $\checkmark$ & & & & $\checkmark$ \\
\hline Suitable IT legacy systems & & & $\checkmark$ & & & & & & \\
\hline Team Work & $\checkmark$ & $\checkmark$ & $\checkmark$ & $\checkmark$ & $\checkmark$ & & $\checkmark$ & $\checkmark$ & $\checkmark$ \\
\hline Implementation strategies & & $\checkmark$ & & $\checkmark$ & $\checkmark$ & & $\checkmark$ & & $\checkmark$ \\
\hline Interdepartmental cooperation & $\checkmark$ & & & & & & & & \\
\hline Data analysis and conversion & & & $\checkmark$ & $\checkmark$ & & & & & $\checkmark$ \\
\hline $\begin{array}{l}\text { Use of vendors' development } \\
\text { tools }\end{array}$ & & & & $\checkmark$ & & & & & \\
\hline Vendor/Customer partnership & & & & $\checkmark$ & $\checkmark$ & & & & \\
\hline Data and information quality & $\checkmark$ & & $\checkmark$ & $\checkmark$ & & & & $\checkmark$ & \\
\hline IT infrastructure & & & $\checkmark$ & & & & & & \\
\hline Empowered decision makers & & $\checkmark$ & $\checkmark$ & $\checkmark$ & & & & & $\checkmark$ \\
\hline
\end{tabular}




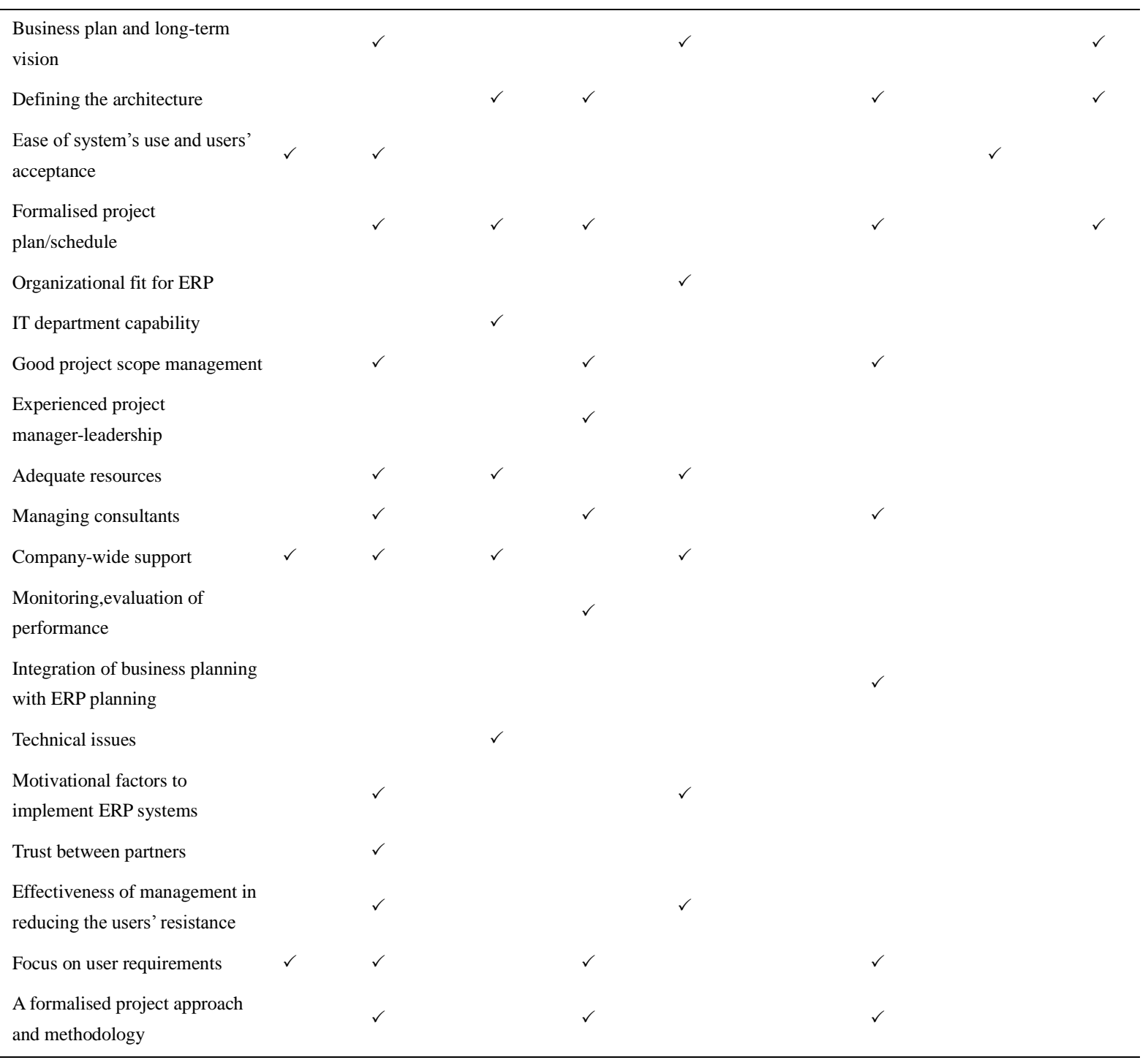

\section{Conclusion}

\subsection{Summary of the Research}

Successfully implementing ERP system has many benefits for organisations. However, on other hand, failing this project would have several negative implications not only on the business but also on the ERP vendor. Therefore, considering all the factors that might affect the success of this project is considered as a priority for all parties involved in it. Therefore, many authors of the scientific journal papers have highlighted the importance of considering the positive and negative factors in the implementation project of the Enterprise Resource Planning (ERP) system. This paper has analysed the articles related to influencing factors that need to be well-thought-out throughout all stages of the ERP system implementation life cycle. This systematic review has focused on two important aspects that are related to the topic of ERP implementation. It measured authors' agreement on the CSFs that accompany the ERP project by recording the frequency of appearance of those factors and then it provided a categorisation for the discovered factors according to stakeholders involved in the ERP implementation and utilisation.

\subsection{Research Contributions}

Many papers or journal articles have studied the Critical Success Factors (CSFs) that influence the ERP implementation and post implementation phases, however, very few or none has considered them from the stakeholders' point of view. Thus, this research has provided a detailed and deep systematic review for the literatures related to CSFs in the ERP implementation. Also, it presented these factors ordered according to their importance while considering the participants' (stakeholders') different point of views, which can be considered 
as a new way to look at the CSFs (see Table 8). This table has provided a tabular categorisation for the positive and negative factors affecting ERP implementation from the stakeholders' perspectives. This classification can make it easier for the members of any the stakeholders groups to find the factors that concern them more easily. Thus, they can achieve more focus and better performance, which can be reflected in a more successful ERP implementation.

\subsection{Research Limitations and Future Work}

As with any other research, this study has some limitations. Firstly, although this study provide a comprehensive literature related to ERP CSFs, however the limited number of papers that consider the CSFs from the perceptives of project managers made data gathering a tremendous effort for authors. Therefore, care should be taken when generalizing the findings of the study. This work can be enhanced and continued by tackling the limitation mentioned before. Also, it can be further improved by conducting a field research in a real life context case study to evaluate the findings and the results concluded in this dissertation. Moreover, research findings could be validated with the stakeholders' groups involved in the ERP implementation project.

\section{References}

Abbasi, M.S., Tarhini, A., Hassouna, M. \& Shah, F. (2015). Social, Organizational, Demography and Individuals' Technology Acceptance Behaviour: A Conceptual Model. European Scientific Journal, 11 (8).

Akkermans, H., \& Helden, K. V. (2002). Vicious and virtuous cycles in ERP implementation: A case study of interrelations between critical success factors. European Journal of Information Systems, 11(1), 35-46. http://dx.doi.org/10.1057/palgrave.ejis.3000418

Alenezi, H., Tarhini, A., \& Masa'deh, R. (2015). Exploring the relationship between information quality and e-government benefits: A literature review. International Review of Social Science and Humanities, 9(1).

Al-Fawaz, K., Al-Salti, Z., \& Eldabi, T. (2008). Critical success factors in ERP implementation: A review. In European and Mediterranean Conference on Information Systems, Dubai, (pp. 25-26).

Al-Mashari, M., Al-Mudimigh, A., \& Zairi, M. (2003). Enterprise resource planning: A taxonomy of critical factors. European Journal of Operational Research, 146, 352-364. http://dx.doi.org/10.1016/S0377-2217(02)00554-4

Barker, T., \& Frolick, M. N. (2003). ERP implementation failure: A case study. Information Systems Management, 20(4), 43-49. http://dx.doi.org/10.1201/1078/43647.20.4.20030901/77292.7

Botta-Genoulaz, V., \& Millet, P. A. (2005). A classification for better use of ERP systems. Computers in Industry, 56, 573-587. http://dx.doi.org/10.1016/j.compind.2005.02.007

Chan, C. T., \& Sin, H. (2010). Critical success factors for ERP implementation in Chinese construction companies. In Industrial Informatics (INDIN), 8th IEEE International Conference. IEEE, pp. 628-633.

Chetcuti, H. R. (2008). ERP Implementation: A multi-stakeholder analysis of critical success factors. WICT Proceedings, 1-6.

Dagher, J., \& Kuzic, J. (2011). ERP implementation in Australia. In Information Technology Interfaces (ITI), Proceedings of the ITI 2011 33rd International Conference on, 2011, IEEE, pp. 379-384.

Deghar, J., \& Kuzic, J. (2010). CSF of ERP in Australia. In Information Technology Interfaces (ITI), 32nd International Conference on, 2010, IEEE, pp. 435-440.

Dezdar, S., \& Ainin, S. (2011). The influence of organizational factors on successful ERP implementation. Management Decision, 49(6), 911-926. http://dx.doi.org/10.1108/00251741111143603

Doom, C., Milis, K., Poelmans, S., \& Bloemen, E. (2010). Critical success factors for ERP implementations in Belgian SMEs. Journal of Enterprise Information Management, 23, 378-406. http://dx.doi.org/10.1108/17410391011036120

Ehie, I. C., \& Madsen, M. (2005). Identifying critical issues in enterprise resource planning (ERP) implementation. Computers in Industry, 56, 545-557. http://dx.doi.org/10.1016/j.compind.2005.02.006

Francoise, O., Bourgault, M., \& Pellerin, R., (2009). ERP implementation through critical success factors' management. Business Process Management Journal, 15(3), 371-394. http://dx.doi.org/10.1108/14637150910960620

Gargeya, V. B., \& Brady, C. (2005). Success and failure factors of adopting SAP in ERP system implementation. Business Process Management Journal, 11(5), 501-516. 
Grossman, T., \& Walsh, J. (2004). Avoiding the pitfalls of ERP system implementation. Information Systems Management, 21, 38-42. http://dx.doi.org/10.1201/1078/44118.21.2.20040301/80420.6

Hailu, A., \& Rahman, S. S. (2012). Evaluation of key success factors influencing ERP implementation success. In Services (SERVICES), 2012 IEEE Eighth World Congress on, 2012, IEEE, pp. 88-91.

Holland, C. P., Light, B., \& Gibson, N. (1999). A critical success factors model for enterprise resource planning implementation. In ECIS, pp. 273-287.

Hong, K. K., \& Kim, Y. G. (2002). The critical success factors for ERP implementation: An organizational fit perspective. Information \& Management, 40, 25-40.

Jarrar, Y. F., Al-mudimigh, A., \& Zairi, M. (2000). ERP implementation critical success factors-the role and impact of business process management. In Management of Innovation and Technology, ICMIT 2000. Proceedings of the 2000 IEEE International Conference on, 2000, IEEE, pp. 122-127.

Khan, K. S., Kunz, R., Kleijnen, J., \& Antes, G. (2003). Five steps to conducting a systematic review. JRSM, 96, 118-121.

Khattak, M. A. O., Iqbal, N., Khattak, M. A., \& Qadeer, A. (2012). Examining critical success factors affecting ERP implementations in Pakistan. Interdisciplinary Journal of Contemporary Research in Business, 3(10), 606-632.

Lai, I. K. (2006). The critical success factors across ERP implementation models: An empirical study in China. International Journal of Enterprise Information Systems (IJEIS), 2, 24-42.

Magal, S. R., \& Word, J. (2009). Essentials of business process and information systems. Hoboken, NJ: John Wiley and Sons.

Monk, F. E., \& Wagner, B. J. (2009). Concepts in enterprise resource planning. International Edition, 25 Thomson Place, Boston: Course Technology Cengage Learning.

Moohebat, M. R., Jazi, M. D., \& Asemi, A. (2011). Evaluation of the ERP implementation at Esfahan Steel Company based on five critical success factors: A case study. International Journal of Business and Management, 6(5), 236-250.

Motwani, J., Subramanian, R., \& Gopalakrishna, P. (2005). Critical factors for successful ERP implementation: exploratory findings from four case studies. Computers in Industry, 56, 529-544. http://dx.doi.org/10.1016/j.compind.2005.02.005

Munir, A., \& Pinedo, C. R. (2013). Critical success factors for ERP implementation in SMEs. Robotics and Computer-Integrated Manufacturing, 29, 104-111. http://dx.doi.org/10.1016/j.rcim.2012.04.019

Ngai, E. W., Law, C. C., \& Wat, F. K. (2008). Examining the critical success factors in the adoption of enterprise resource planning. Computers in Industry, 59, 548-564. http://dx.doi.org/10.1016/j.compind.2007.12.001

Nour, M. A., \& Mouakket, S. (2011). A classification framework of critical success factors for ERP systems implementation: A multi-stakeholder perspective. International Journal of Enterprise Information Systems (IJEIS), 7, 56-71. http://dx.doi.org/10.4018/jeis.2011010104

Okrent, M. D., \& Vokurka, R. J. (2004). Process mapping in successful ERP implementations. Industrial Management \& Data Systems, 104, 637-643. http://dx.doi.org/10.1108/02635570410561618

Orozco, J., Tarhini, A., \& Masa'deh, R. (2015). A framework of IS/business alignment management practices to improve the design of IT Governance architectures. International Journal of Business and Management, 10(4).

Pant, R., \& Willcocks, L. (2007). Critical success factors in international ERP implementations: A case research approach. Journal of Computer Information Systems, 47, 60-70.

Rabaa'i, A. A. (2009). Identifying critical success factors of ERP Systems at the higher education sector. In ISIICT 2009: Third International Symposium on Innovation in Information \& Communication Technology (pp. 133-147).

Salimifard, K., Ebrahimi, M., \& Abbaszadeh, M. A. (2010). Investigating critical success factors in ERP implementation projects. IEEE International Conference on Advanced Management Science, 3, 82-86.

Somers, T. M., \& Nelson, K. (2001). The impact of critical success factors across the stages of enterprise resource planning implementations. System Sciences, Proceedings of the 34th Annual Hawaii International Conference. IEEE, p. 10. 
Tarhini, A., Hassouna, M., Abbasi, M. S., \& Orozco, J. (2015). Towards the acceptance of RSS to support learning: An empirical study to validate the technology acceptance model in Lebanon. Electronic Journal of e-Learning, 13(1), 30-41.

Tarhini, A., Scott, M., Sharma, K. S., \& Abbasi, M. S. (2015). Differences in intention to use educational rss feeds between Lebanese and British Students: A multi-group analysis based on the technology acceptance model. Electronic Journal of e-Learning, 13(1), 14-29.

Tarhini, A., Teo, T., \& Tarhini, T. (2015). A cross-cultural validity of the E-Learning Acceptance Measure (ElAM) in Lebanon and England: A confirmatory factor analysis. Education and Information Technologies. http://dx.doi.org/10.1007/s10639-015-9381-9

Umble, E. J., Haft, R. R., \& Umble, M. M. (2003). Enterprise resource planning: Implementation procedures. $\begin{array}{llll}\text { European Journal of Operational Research, 146(2), 241-257. } & \text {. }\end{array}$ http://dx.doi.org/10.1016/S0377-2217(02)00547-7

Van Hau, T. T., \& Kuzic, J. (2010). Change management strategies for the successful implementation of enterprise resource planning systems. Knowledge and Systems Engineering (KSE), Second International Conference, IEEE, pp. 178-182.

Velcu, O. (2010). Strategic alignment of ERP implementation stages: An empirical investigation. Information \& Management, 47(3), 158-166. http://dx.doi.org/10.1016/j.im.2010.01.005

Wang, E. T., Shih, S. P., Jiang, J. J., \& Klein, G. (2008). The consistency among facilitating factors and ERP implementation success: A holistic view of fit. Journal of Systems and Software, 81, 1609-1621. http://dx.doi.org/10.1016/j.jss.2007.11.722

Wong, A., Scarbrough, H., Chau, P. Y. K., \& Davison, R. (2005). Critical failure factors in ERP implementation. In Proceedings of 9th Pacific Asia Conference on Information Systems (pp. 492-505). Bangkok, Thailand.

Xue, Y., Liang, H., Boulton, W. R., \& Snyder, C. A. (2004). ERP implementation failures in China: Case studies with implications for ERP vendors. International Journal of Production Economics, 97(3), 279-295. http://dx.doi.org/10.1016/j.ijpe.2004.07.008

Yang, C., \& Su, Y. F. (2009). The relationship between benefits of ERP systems implementation and its impacts on firm performance of SCM. Journal of Enterprise Information Management, 22(6), 722-752. http://dx.doi.org/10.1108/17410390910999602

Yanhong, Z. (2009). ERP implementation process analysis based on the key success factors. Information Technology and Applications, 2009, IFITA'09. International Forum on 2009, IEEE, pp. 25-27.

Yusuf, Y., Gunasekran, A., \& Abthorpe, M. S. (2004). Enterprise information systems project implementation: A case study of ERP in Rolls-Royce. International Journal of Production Economics, 87(3), 251-266. http://dx.doi.org/10.1016/j.ijpe.2003.10.004

\section{Copyrights}

Copyright for this article is retained by the author(s), with first publication rights granted to the journal.

This is an open-access article distributed under the terms and conditions of the Creative Commons Attribution license (http://creativecommons.org/licenses/by/3.0/). 